\title{
New articulated asteroids (Echinodermata, Asteroidea) and ophiuroids (Echinodermata, Ophiuroidea) from the Late Jurassic (Volgian/Tithonian) of central Spitsbergen
}

\author{
Julie ROUSSEAU ${ }^{1, *}$, Andrew Scott GALE ${ }^{2} \&$ Ben THUY ${ }^{3}$ \\ ${ }^{1} 1111$ Belle Pre Way, Apt. 537, Alexandria, VA, 22314, United States of America. \\ ${ }^{2}$ School of Earth \& Environmental Sciences, University of Portsmouth, Burnaby Building, \\ Burnaby Road, Portsmouth, PO1 3QL, United Kingdom. \\ ${ }^{3}$ Department of Palaeontology, Natural History Museum Luxembourg, \\ Luxembourg-City, Luxembourg. \\ *Corresponding author: rousseauj19@gmail.com \\ 2Email: andy.gale@port.ac.uk \\ ${ }^{3}$ Email: ben.thuy@mnhn.lu \\ ${ }^{1}$ urn:lsid:zoobank.org:author:C58AF561-3A85-4615-B5A4-BA3D323F7A25 \\ ${ }^{2}$ urn:1sid:zoobank.org:author:092855B9-CBE4-41F9-9861-3BEA1FDE50F1 \\ ${ }^{3}$ urn:lsid:zoobank.org:author:04186A8C-3F0D-485E-834A-08414A217ACA
}

\begin{abstract}
The Late Jurassic-Early Cretaceous Slottsmøya Member of the Agardhfjellet Formation in central Spitsbergen has yielded two new species of asteroids and two species of ophiuroids, one of which is described as new. Polarasterias janusensis Rousseau \& Gale gen. et sp. nov. is a forcipulatid neoasteroid with elongated arms, small disc and very broad ambulacral grooves with narrow adambulacrals. Savignaster septemtrionalis Rousseau \& Gale sp. nov. is a pterasterid with welldeveloped interradial chevrons. The Spitsbergen specimens are the first described articulated material of Savignaster and reveal the overall arrangement of the ambulacral groove ossicles. Ophiogaleus sp. is an ophiacanthid with relatively long jaws and lateral arm plates, with a coarsely reticulate outer surface. Here again, we report the first articulated skeletons of this genus, providing unprecedented insights into the disc morphology. Ophioculina hoybergia Rousseau \& Thuy gen. et sp. nov. is an ophiopyrgid with a well-developed arm comb and tentacle pores reduced to within-plate perforations starting at median arm segments. These new finds are important additions to the asterozoan fossil record with regard to their good degree of articulation and the high latitudinal position of the localities. They significantly add to the set of exhaustively known fossil asterozoan taxa which play a key role in the phylogenetic analysis and reconstruction of evolutionary history.
\end{abstract}

Keywords. Polarasterias janusensis gen. et sp. nov., Savignaster septemtrionalis sp. nov., Ophiogaleus sp., Ophioculina hoybergia gen. et sp. nov., Slottsmøya Lagerstätte.

Rousseau J., Gale A.S. \& Thuy B. 2018. New articulated asteroids (Echinodermata, Asteroidea) and ophiuroids (Echinodermata, Ophiuroidea) from the Late Jurassic (Volgian/Tithonian) of central Spitsbergen. European Journal of Taxonomy 411: 1-26. https://doi.org/10.5852/ejt.2018.411 


\section{Introduction}

Anew asterozoan assemblage was discovered in Volgian deposits of central Spitsbergen. The fossils were collected by the Spitsbergen Jurassic Research Group (SJRG), an international team of palaeontologists and geologists, while excavating marine reptile fossils in the area around Knorringfjellet and Janusfjellet (Fig. 1A). This area, the Slottsmøya Lagerstätte (Hurum et al. 2012), is a new hotspot for arctic palaeontology and has yielded an abundance of fossil vertebrates, macro-invertebrates and microfossils. Recent publications highlighting the Slottsmøya fauna include Delsett et al. (2016) for marine reptiles and Hryniewicz et al. (2015) for macro-invertebrates from hydrocarbon seep carbonates. In the Slottsmøya Lagerstätte, the asteroids and ophiuroids are preserved in a good degree of articulation. This is relatively rare for these echinoderm classes and requires specific burial conditions (see, e.g., Donovan 1991). The extreme geographic situation of the study area, occurring at a latitude of more than $78^{\circ}$ North, moreover makes this discovery an exciting addition to the fossil record.

\section{Mesozoic Boreal echinoderms}

Historically, invertebrate biostratigraphy has been the major goal of paleontological fieldwork in Mesozoic deposits of the high arctic. Echinoderms, however, having traditionally been of little use in stratigraphy, have suffered a negative collection bias in those regions. Brief mentions of echinoderm presence can be found within extensive invertebrate biostratigraphy reports (e.g., Trautschold 1866, 1877; Spath 1935, 1947; Jeletzky 1973; Fürsich 1984a, 1984b; Gerasimov et al. 1995, 1996), but descriptions and illustrations are always extremely limited.

While crinoids and echinoids are relatively well represented in the Boreal Mesozoic fossil record, asteroids and ophiuroids are extremely rare (see Rousseau \& Nakrem 2012 for a review). Given their multi-element structure and the high susceptibility to post-mortem disarticulation, fossil articulated specimens are preserved only under specific burial conditions (Ausich 2001). Before the discovery of the Slottsmøya specimens by the SJRG, only a handful of specimens had been reported from the Mesozoic arctic.

For asteroids, previous work on Spitsbergen has led to the report of undescribed fossils from the AptianAlbian (Lower Cretaceous) Carolinefjellet Formation (Nagy 1963). To our knowledge, no specimens have been reported from the Russian arctic, but two Mesozoic occurrences in the Moscow region have been published. A single disarticulated plate referred to "Asterias" (= Tylasteria Valette, 1929) jurensis Münster in Goldfuss, 1831 (Trautschold 1866: 3, pl. 1 fig. 2) has been reported from the Jurassic. Gerasimov et al. (1996) also mentioned the presence of Goniaster cf. jurensis Agassiz, 1836 in Callovian deposits of the Moscow region. Until this publication, the best described Mesozoic Boreal asteroid fossil came from the Ryazanian Crinoid Berg Member (Hesteelv Formation), South-West Jameson Land, Greenland, where Spath (1947) briefly described one asteroid which he provisionally referred to Astropecten (?) sp. indet.

The literature on the fossil record of arctic Mesozoic ophiuroids is similarly scarce. Spath (1935: pl. 11, fig. 2) assigned to Ophiurites sp. a single, articulated specimen found in the Upper Oxfordian Kap Leslie Formation in Milne Land, Greenland. A second ophiuroid specimen was reported from the Early Cretaceous Kingak Formation, Old Crow area, northern Yukon, Canada. Briefly described by Corgan (1962) as Ophiura sp., this articulated disc seen in dorsal aspect with five partial arms without any sign of spinosity, is poorly illustrated. The last published arctic Mesozoic ophiuroid specimen was discovered on Spitsbergen by Nagy (1963: fig. 2) in the Early Cretaceous Carolinefjellet Formation of the Kjellströmdalen area. This unidentified ophiuroid consists of a small articulated disc showing the dorsal side, with preserved portions of five short, tapering arms. 

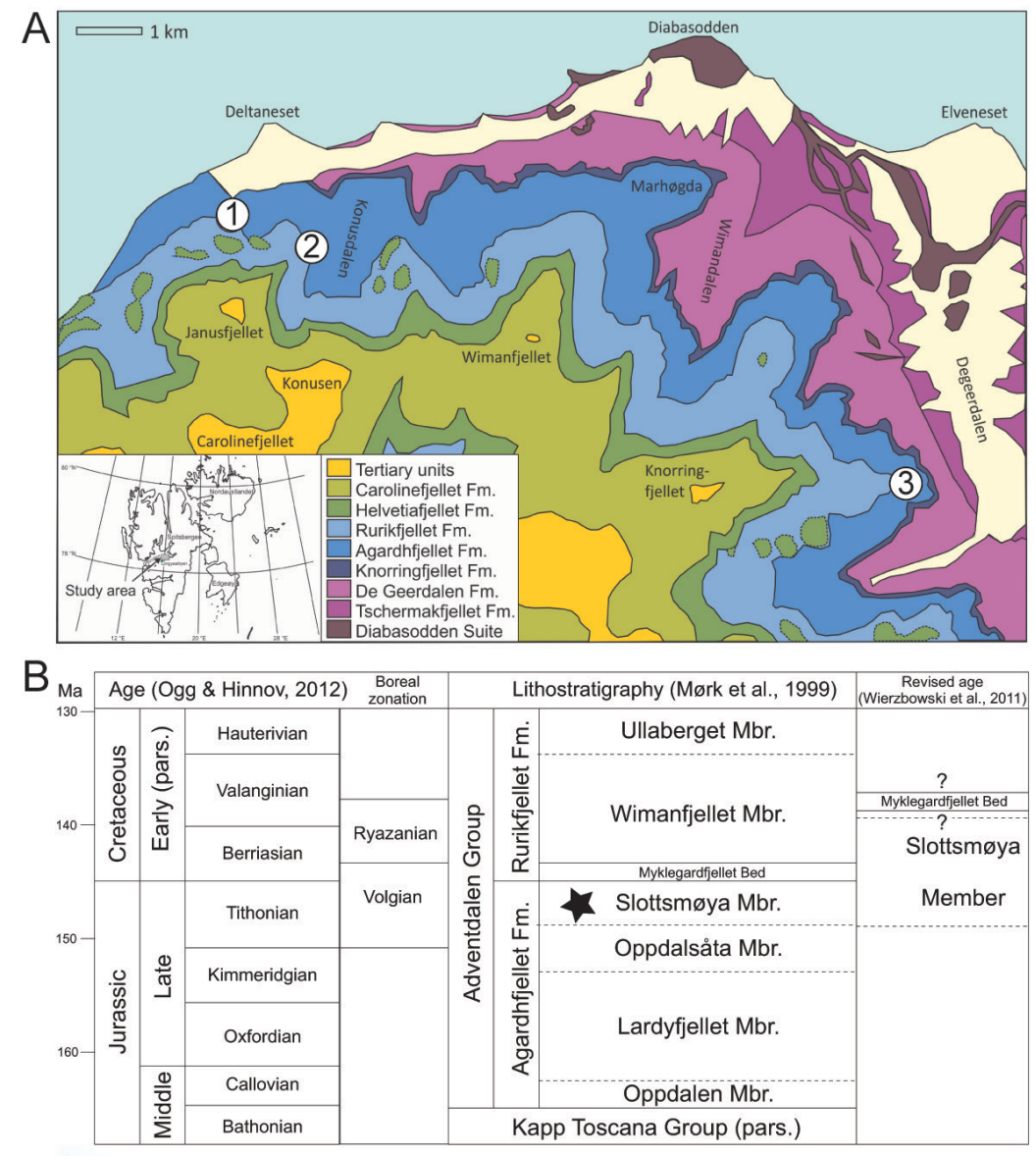

C

D

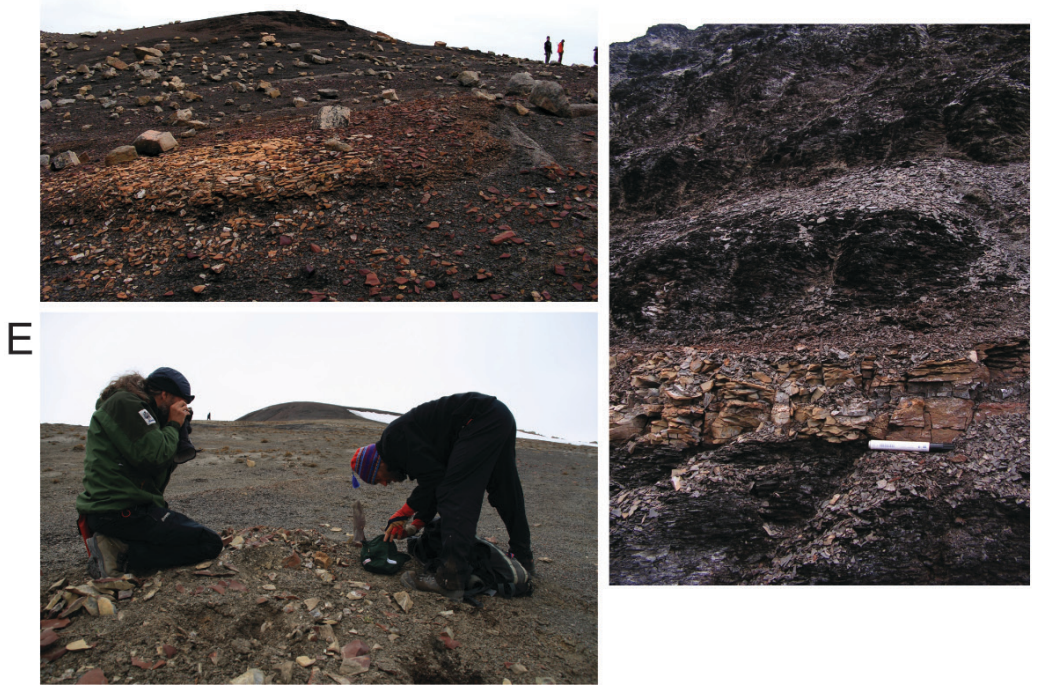

Fig. 1. A. Simplified geological map of the study area in Sassenfjorden, central Spitsbergen, with location of the Janusfjellet (1), Konusdalen (2) and Knorringfjellet (3) collection sites. Redrawn and adapted from Dallmann et al. (2001) by H.A. Nakrem, used with permission. B. Chrono- and lithostratigraphic correlation for the Late Jurassic-Earliest Cretaceous interval of central Spistbergen. The Slottsmøya Member is indicated by a star. Modified with permission from Dalseg et al. (2016). C. Janusfjellet locality, $78^{\circ} 20^{\prime} 35.4^{\prime \prime} \mathrm{N}, 15^{\circ} 49^{\prime} 85.2^{\prime \prime}$ E, surface outcrop. D. Konusdalen locality, 78 $19^{\prime} 97.1^{\prime \prime} \mathrm{N}$, $15^{\circ} 52^{\prime} 15.5^{\prime \prime}$ E, in situ layer. E. Knorringfjellet locality, N 78 $18^{\prime} 04.4^{\prime \prime}$ E $16^{\circ} 16^{\prime} 02.0^{\prime \prime}$, surface outcrop. 
None of these previously published records contains sufficient information for good comparisons with other Boreal Mesozoic material. Here, we present the first systematic description of four asteroid and ophiuroid species from the Mesozoic arctic, greatly improving the fossil record for this temporal and geographic range.

\section{Palaeogeographic and stratigraphic setting}

The Mesozoic rocks exposed in central Spitsbergen were deposited at a relatively high latitude within the Palaeo-Barents Sea (Zacharov et al. 2002; Hryniewicz et al. 2015). Cold, high-Boreal water temperatures of $5-10^{\circ} \mathrm{C}$ have been suggested for the Tithonian-Valanginian by Ditchfield (1997). The area was connected to the rest of the Boreal region and at least periodically isolated from the lower latitude Tethyan region which is today represented by rich, well-known European fossil localities (see e.g., Goldring \& Stephenson 1972; Roman et al. 1993; Breton et al. 1994; Thuy et al. 2011).

All specimens described here were found within the Slottsmøya Member, the uppermost unit of the Agardhfjellet Formation (Fig. 1B). In the study area, this member is a ca 70-meter-thick succession of grey to black shales and siltstones irregularly interbedded with concretionary siderite and dolomite, deposited in an open-marine shelf environment with estimated water depths of 100-150 meters (Dypvik et al. 1991; Mørk et al. 1999; Hammer et al. 2011, 2012; Collignon \& Hammer 2012; Hryniewicz et al. 2015). It has been interpreted as a transgressive unit with slightly dysoxic shelf conditions and periodic fluctuation in the oxygenation of the bottom water (Nagy et al. 2009; Hammer et al. 2011, 2012; Collignon \& Hammer 2012; Hjálmarsdóttir et al. 2012). Seep carbonate bodies have been identified and described from the uppermost section of the member (Hammer et al. 2011; Wierzbowski et al. 2011; Hryniewicz et al. 2012, 2015).

The Slottsmøya Member has been assigned a Volgian age based on foraminifera and ammonite biostratigraphy (Parker 1967; Birkenmajer et al. 1982; Ershova 1983; Nagy \& Basov 1998; Wierzbowski et al. 2011) and carbon-isotope stratigraphy (Hammer et al. 2012; Koevoets et al. 2016). The Boreal Volgian stage has been roughly correlated with the Tithonian international standard (Fig. 1B; Houša et al. 2007; Zacharov \& Rogov 2008; Rogov \& Zacharov 2009). Wierzbowski et al. (2011) recently pushed the uppermost boundary of the Slottsmøya Member up to the Upper Ryazanian (Berriasian international standard), but this adjustment is inconsequential for our purpose as all echinoderms described here were found within the middle part of the section and are thus unequivocally Tithonian in age (Hryniewicz et al. 2015: fig. 2).

The fossils were preserved in a ca 20-cm-thick layer of red to yellowish sideritic concretion in the middle part of Slottsmøya Member (Collignon \& Hammer 2012: fig. 4; Hryniewicz et al. 2015: fig. 2). Such concretion levels within the shales are interpreted as isolated storm events in an otherwise quiet, oxygen-deficient sea-bottom environment with low sedimentation rate (Rousseau \& Nakrem 2012). No break in sedimentation can be recognized within the concretion layers which are each assumed to represent a single burial event. This sudden sediment input on the muddy seafloor smothered and effectively trapped the benthic asterozoans. The cold water temperatures of this high-latitude marine shelf could additionally have enhanced a good preservation quality by significantly slowing down decay processes. Dysoxicity of the sea bottom also prevented major postburial disturbance. Trapped by these fast and sudden depositional events, echinoderms were preserved with a good degree of articulation. This depositional environment model is consistent with most known echinoderm Lagerstätten preserving articulated asterozoans as their fragile structures, such as asteroid and ophiuroid arms, disarticulate within days after death (Schäfer 1972; Lewis 1986, 1987; Allison 1990).

The most extensive of these sideritic concretion layer extends at least from Janusfjellet (Janus Mountain) to Konusdalen (Konus valley) and was intensively sampled both as surface exposure at Janusfjellet 
ROUSSEAU J. et al., New articulated asteroids and ophiuroids from the Jurassic of Spitsbergen

(Fig. 1A Site 1, 1C) and in-situ in Konusdalen (Fig. 1A Site 2, 1D). It preserved one asteroid and two ophiuroid species as part of a low-diversity assemblage of articulated fossil echinoderms also including the echinoid Hemipedina sp. and the isocrinid Chariocrinus sp. (Rousseau \& Nakrem 2012). The overall low diversity of the assemblage is not surprising for this high-latitude environment. The Knorringfjellet locality (Fig. 1A Site 3,1E) contained a single species of asteroid, found within a slightly younger, isolated, sideritic concretion lens which also contained scaphopods and disarticulated bivalves.

\section{Material and methods}

The material described here was collected during the palaeontological expeditions of the Spitsbergen Jurassic Research Group to central Spitsbergen between 2008 and 2011. Collection sites are identified in Fig. 1. All specimens are deposited in the palaeontological collection of the Natural History Museum, Oslo (PMO). The fossils were nicely revealed by natural erosion and very little preparation was necessary. In most of the specimens, the splitting plane of the sideritic nodule runs through the skeleton, exposing sections of the plates. This rather unusual preservation mode is ideal to show the anatomical disposition and outline of the skeletal plates, but mostly fails to show microscopical features of the external plate surfaces.

Macroscopic photographs were taken using a Nikon D300 camera mounted on a projection stand with two light sources, each a $12 \mathrm{~V}$ desk lamp, projected from the top right and left corners. Stereo microscopic pictures were taken using a Keyence VHX-500F digital microscope at the University of Göttingen, Germany.

Morphological measurements were taken using a Cocraft digital caliper model 40-7541 with an imprecision of $\pm 0.02 \mathrm{~mm}$. Anatomical terminology mostly follows Gale (2011a) for asteroids and Martynov (2010), Thuy \& Stöhr (2011), Stöhr et al. (2012) and Thuy \& Stöhr (2016) for ophiuroids. Synonyms and higher taxonomy references were compiled from the World Asteroidea database (Mah 2016) and the World Ophiuroidea database (Stöhr et al. 2016). Ophiuroid classification follows the phylogeny-based scheme proposed by O'Hara et al. (2017).

\section{Results}

Phylum Echinodermata Bruguière, 1791

Class Asteroidea de Blainville, 1830

Order Forcipulatida Perrier, 1884

Family Asteriidae Gray, 1840

Polarasterias Rousseau \& Gale gen. nov. urn:lsid:zoobank.org:act:6A46CC92-9366-4DCB-94B5-7313D76EB0A1

\section{Type species}

Polarasterias janusensis Rousseau \& Gale gen. et sp. nov., by original designation.

\section{Diagnosis}

Asteriid with elongated arms, small disc, very broad ambulacral grooves with narrow adambulacrals and weakly developed or absent actinals. Abactinals cruciform, numerous, forming a rectilinear grid arranged in regular transverse rows of seven or more plates on each side of the arm. Tube feet strongly quadriserial. 


\section{Etymology}

To emphasize the polar situation of the locality and with reference to the North Star Polaris.

Polarasterias janusensis Rousseau \& Gale gen. et sp. nov. urn:lsid:zoobank.org:act:8A3128E8-171C-400D-8BEA-CFA29FADBC41

Fig. 2

\section{Diagnosis}

As for genus.

\section{Etymology}

The specific epithet refers to the Janus mountain (Janusfjellet) locality.

\section{Material examined}

\section{Holotype}

NORWAY: central Spitsbergen, Janusfjellet, 78²0'35.4" N, 15²49'85.2" E (PMO 218.011a).

\section{Paratypes}

NORWAY: same location as for holotype (PMO 217.936, PMO 217.982, PMO 218.069). More than 50 partial specimens were collected.

\section{Type stratum}

Lower Middle Volgian (Middle Tithonian), Slottsmøya Member, Agardhfjellet Formation.

\section{Description}

The holotype, PMO 218.011a (Fig. 2A-C), is a relatively complete specimen showing an articulated disc with five arms, two of which extend to the tip, preserved in a cut-through manner (i.e., split horizontally approximately along the ambitus) and clearly showing the form and arrangement of the ambulacral groove ossicles. The arms are elongated and the disc is very small. The arms taper slowly and the interbrachial angle is acute (major radius $=65 \mathrm{~mm}$, minor radius $=8 \mathrm{~mm}$ ). The ambulacral groove is very broad (width $=8 \mathrm{~mm}$ ) and the ambulacrals occupy roughly $80 \%$ of the arm width. The inferomarginals are barely visible on the actinal surfaces of the arms. The presence of actinal ossicles cannot be confirmed from the material available, but the very acute interradii cannot have had significant actinal interradial areas and if actinals were present, they must have been restricted to the proximal arms. There are about 70 ambulacrals and adambulacrals in each half radius. The podial openings for tube feet are strongly quadriserial along the total length of the arms (Fig. 2A, C). The ambulacrals have well demarcated heads, shaft and bases and are not very foreshortened (Fig. 2C) as in many asteriids (Gale 2011a). The ambulacral head is angled to the shaft and the base, and strong dentition is present. The ambulacrals are rectangular in actinal view, short and broad, and have a strongly concave proximal surface for a large adambulacral muscle. The adambulacrals have a prominent distal heel contacting the distal ambulacral base. Each adambulacral carried two spines (diplacantid condition), one of which, probably the outer, is significantly larger than the other (Fig. 2C). The conical, elongated, adambulacral spines at the base of the arm are over $4 \mathrm{~mm}$ in length and form a distally directed fringe to the arm. Abundant straight pedicellariae are seen in cross section scattered among the adambulacral spines (Fig. 4B-C). These include $\varepsilon$ shaped basal pieces which possess tall median ridges for insertion of the inner longitudinal adductor muscle (Gale 2011a). 

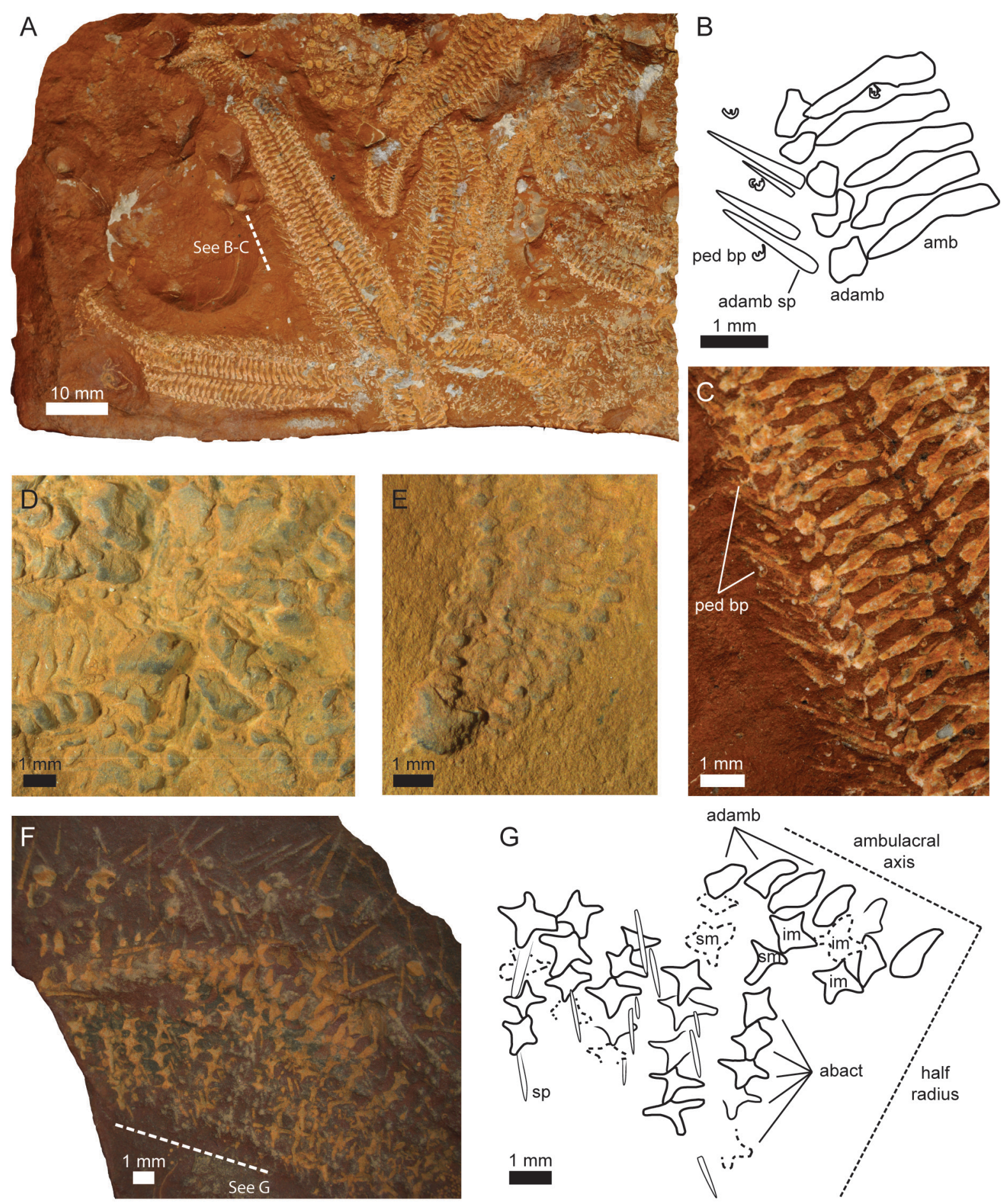

Fig. 2. Polarasterias janusensis Rousseau \& Gale gen. et sp. nov. A-C. Holotype PMO 218.011a. A. Nearly complete specimen preserved in a cut-through fashion. B. Drawing detail from ambulacral groove showing ambulacrals, adambulacrals, adambulacral spines and scattered valves of forcipulate pedicellariae. C. Portion of arm illustrated in B, basal pieces of straight pedicellariae visible in cross section. D. Paratype PMO 217.982, oral region in actinal view. E. Paratype PMO 217.936, Arm tip showing terminal ossicle. F-G. Paratype PMO 218.069. F. Obliquely compressed radius showing adambulacrals, marginals, and columns of abactinal ossicles. G. Drawing detail from F. Abbreviations: abact $=$ abactinal ossicle; adamb $\mathrm{sp}=$ adambulacral spine; adamb $=$ adambulacral; $\mathrm{amb}=$ ambulacral; $\mathrm{im}=$ inferomarginal; ped $\mathrm{bp}=$ basal piece of pedicellariae; $\mathrm{sm}=$ superomarginal; $\mathrm{sp}=$ spine. 
A partly disarticulated mouth frame seen from the actinal surface is visible on paratype PMO 217.982 (Fig. 2D) and shows the presence of an adoral carina involving two or three adambulacrals. The oral ossicles are well preserved and have a short, rectangular oral surface which bears two spine articulations.

The terminal ossicle is well preserved in paratype specimen PMO 217.936 (Fig. 2E), where it is triangular and as broad as long with a strongly convex distal margin.

Paratype specimen PMO 218.069 (Fig. 2F-G) shows the abactinal surface of an arm. The abactinal ossicles are cruciform, with four processes which contacted adjacent rows and columns, and are arranged in well-marked imbricate transverse columns, with up to seven ossicles in each half radius. The largest two abactinals are present adjacent to the adambulacral, and are identified as the inferoand superomarginals (Fig. 2G). Up to five slightly smaller abactinals are also present in each column. However, it is not possible to identify radials and adradials, so the exact numbers of plates present cannot be discerned. The abactinal ossicles formed a rectilinear reticulate structure, with the spaces occupied by papular openings, and the centre of each abactinal plate carried a long spine.

\section{Remarks}

This new asteroid is clearly a forcipulatid neoasteroid as forcipulate pedicellariae are present. It could potentially belong to the Terminasteridae Gale, 2011a, Zoroasteridae Sladen, 1889 or Asteriidae Gray, 1840 which can be difficult to separate in fossil material, because the families have many morphological features in common (Blake 1990). The single most diagnostic feature of the Asteriidae, the presence of both straight and crossed pedicellariae, unfortunately cannot be confirmed in this material. However, various lines of morphological evidence permit assignation to the Asteriidae. These include the form of the terminal ossicle, which is relatively short and broad as in asteriids while markedly elongated in terminasterids and zoroasterids. Moreover, the morphology of the oral ossicle is similar to that in extant asteriids (Gale 2011a), and the shape of the basal piece of the straight pedicellariae, with a tall median ridge, is also typically asteriid. The strongly quadriserial arrangement of the tube feet along the entire length of the groove is also an asteriid character (Blake 1990). The arrangement of the abactinal ossicles in up to seven transverse rectilinear columns is not typical of extant asteriids, in which a more or less irregular network of plates extends between the superomarginals and the radials (e.g., Fisher 1928: pls 67, 44, 61; Gale \& Villier 2013).

Polarasterias janusensis gen. et sp. nov. differs significantly from other described Jurassic and Cretaceous asteriid genera. Blake (1990) described two new genera and species from the Hettangian (Early Jurassic) of Germany, Germanasterias amplipapularia Blake, 1990 and Hystrixasterias hettangiurnus Blake, 1990, which he assigned to the Asteriidae. These differ from the described species in the presence of relatively broad actinal interareas, the relatively closed ambulacral groove and the more rapidly tapering arms. Additionally, Germanasterias Blake, 1990 is characterized by having very coarse, numerous, adambulacral spines which are not seen in the Janusfjellet material. Argoviaster occultus Hess, 1972 and Dermaster boehmi de Loriol, 1899 were described from the Bajocian of Switzerland (Hess 1972). Both have stout, relatively short, rapidly tapering arms and narrow ambulacral grooves. The species from Spitsbergen also differs from Cretasterias reticulatus Gale \& Villier, 2013 in its more strongly quadriserial tube feet, and the more numerous columns of abactinal ossicles, but agrees in the overall shape of the arms of and the rectilinear arrangement of the abactinal ossicles.

Modern members of the Asteriidae family are slow-moving, epifaunal carnivores living on the sea bottom. The relatively large body size, small disc size, multi-element arms, quadriserial tube feet and adoral carina present in Polarasterias janusensis gen. et sp. nov. are all features which favor a predatory mode of feeding (Blake 1987, 1990). The wide ambulacral groove, covered with numerous tube feet, provided a strong adhesion force which could have helped Polarasterias janusensis gen. et sp. nov. 
to grab and hold its prey. Modern predatory asteroids feed mostly on bivalves, gastropods and other echinoderms, including other asteroids, ophiuroids and echinoids, and are known to form large feeding groups (Spencer \& Wright 1966). Similarly, it is likely that Polarasterias janusensis gen. et sp. nov. lived gregariously as epifauna on the Spitsbergen muddy seafloor, where it hunted for bivalves and echinoderms.

Order Velatida Perrier, 1884

Family Pterasteridae Perrier, 1875

Genus Savignaster Gale, 2011

\section{Type species}

Savignaster wardi Gale, 2011a.

\section{Diagnosis}

Pterasterid bearing megapaxillae with short, stout, vase-shaped pedicels, distally hollow; adambulacrals with short, broad, rod-like lateral extensions, carrying fan-shaped, trellis-like spines at their lateral margin.

Savignaster septemtrionalis Rousseau \& Gale sp. nov. urn:1sid:zoobank.org:act:EF6444E7-C91F-478B-9575-F7E67E4C58D2

Fig. 3

\section{Diagnosis}

Savignaster in which the ambulacral bases and shafts are very elongated and poorly differentiated.

\section{Etymology}

The specific epithet is from the Latin 'septemtrionalis', northern, in reference to the high latitudinal position of the locality.

\section{Material examined}

\section{Holotype}

NORWAY: central Spitsbergen, Knorringfjellet, 78 $18^{\prime} 04.4^{\prime \prime}$ N, 16²16'02.0" E (PMO 218.000).

\section{Paratypes}

NORWAY: same location as for holotype (PMO 217.976, PMO 217.977, PMO 217.978, PMO 218.008). Ten partial specimens were found at the type locality.

\section{Type stratum}

Middle Volgian (Tithonian), Slottsmøya Member, Agardhfjellet Formation.

\section{Description}

The holotype PMO 218.000 (Fig. 3A-B) is an articulated arm and interradial area, which also shows some portions of a second arm belonging to the same individual. Ambulacrals and adambulacrals are clearly exposed in a transverse section of the groove and disc. The arms are triangular and taper rapidly, and the interradius is acutely angled. The major radius of the holotype (R) is $45 \mathrm{~mm}$, the minor radius (r) $15 \mathrm{~mm}$. The base of the arm is $20 \mathrm{~mm}$ across. There are over 30 pairs of ambulacrals and adambulacrals present in each half radius and the two plate rows are of approximately equal width. 
The ambulacral heads have a large triangular proximal extension and are imbricated proximally. The ambulacrals shafts and bases are elongated and narrow and set nearly at right angles to the axis of the arm. Paratypes PMO 217.976 (Fig. 3C) and PMO 217.977 (Fig. 3D) also show the arrangement of the ambulacral ossicles. Ambulacrals and adambulacrals alternate, and the adambulacrals are slanted laterally and distally. The adambulacrals comprise two parts; a thicker adradial region and a narrow, parallel sided elongated adambulacral extension as in Savignaster wardi (Gale 2011a, 2011b). The adradial portions are thickened where spine bases were present. In the holotype, scattered abactinal ossicles lie alongside the lateral margin of the adambulacrals (Fig. 3A-B) and, evidently, the individual was obliquely compacted with the abactinal surface pushed over the adambulacrals. The abactinal ossicles are poorly preserved, but include forms with a pedicel and at least some are identifiable as megapaxillae. Interradial chevron ossicles are present in the interradial region. They form a laterally diverging $\mathrm{V}$-arrangement of nine to ten closely spaced plate pairs situated symmetrically across the interradial line (Fig. 4A-B).

In paratype specimen PMO 217.978, poorly preserved flattened spines are seen attached to the lateral margins of the adambulacrals (Fig. 3E). These have a rounded basal portion and a flattened, trellis-like distal part; they are comparable in shape with spines on the holotype of Savignaster wardi (Gale 2011a: pl. 21 figs 2, 5). This particular spine morphology is also clearly visible in paratype PMO 218.008 (Fig. 3F), a partial arm preserving multiple articulated spines.

\section{Remarks}

The specimens consist of individuals which have split horizontally approximately along the plane of the ambitus, an unusual preservation mode. The presence of interradial chevron ossicles permit placement of the new species in the clade including Korethrasteridae and Pterasteridae (Gale 2011a, 2011b). It can furthermore be assigned to Savignaster based on the similarity of the shape (long adambulacral extensions) of the adambulacrals to those of $S$. wardi Gale, 2011. The ambulacrals differ significantly in shape from those of both S. wardi and S. trimbachensis (Gale 2011a: pl. 23) in which club-shaped, quite well-differentiated ambulacral bases are present; the ambulacral shafts and bases are considerably elongated, undifferentiated, and very short with parallel sides in S. septemtrionalis sp. nov. Savignaster was identified by Gale (2011a, 2011b) as a basal pterasterid, which possesses most, but not all of the synapomorphies of extant members of the family. Savignaster is known from the Bathonian of Kutch, India (A.S. Gale, pers. obs.), the Oxfordian of Switzerland and France (Gale 2011a, 2011b) and now from the Volgian of Spitsbergen. The Knorringfjellet specimens represent the first articulated material of the genus Savignaster in which the arrangement of the ambulacral groove ossicles can be seen.

In the original description of the genus Savignaster, Gale (2011a) inferred that the type species lacked the abactinal canopy typically present in pterasterids. In Savignaster, the abactinal and lateral adambulacral spines are enlarged and highly muscularized, features which would prevent their enclosure within a canopy membrane. However, as noted by Gale (2011a), Savignaster was probably capable of reducing its coelomic volume by contracting muscles present between abactinal ossicles, thus pushing out the papulae and increasing its respiratory surface. Nance \& Braithwaite (1972) discussed a similar contraction capacity in Recent mucus-secreting Pteraster tesselatus and Gale (2011a) suggested improvement of oxygen uptake as a driver of specialized pterasterid evolution. Accordingly, Savignaster septemtrionalis sp. nov. would have been well adapted to the fluctuating oxygen availability in the Late Jurassic PalaeoBarents Sea of Spitsbergen. 
A

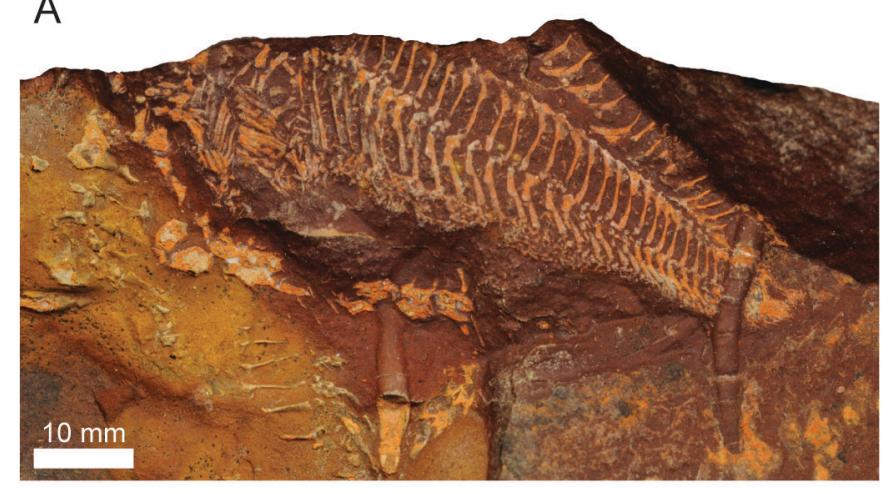

C

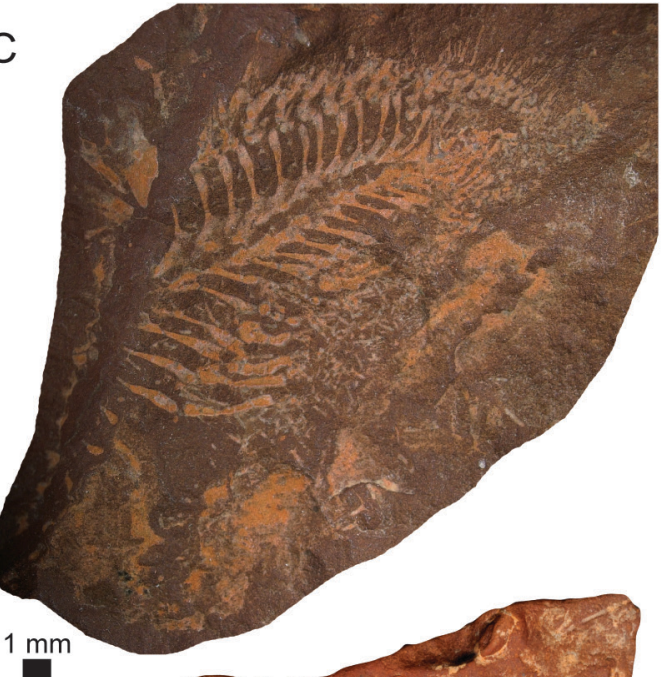

E

E

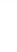

B 8
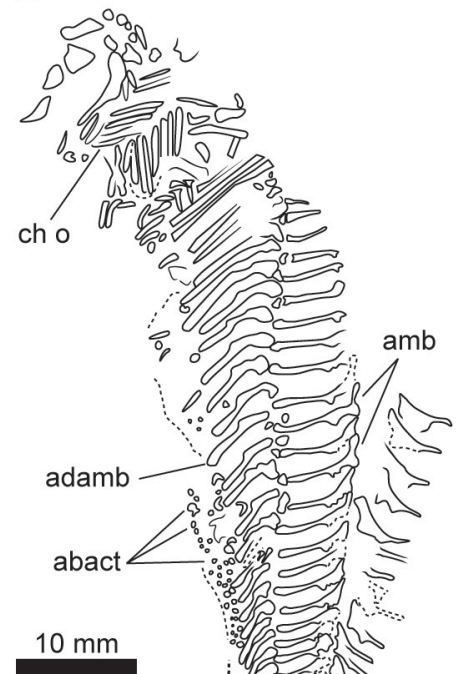

$10 \mathrm{~mm}$
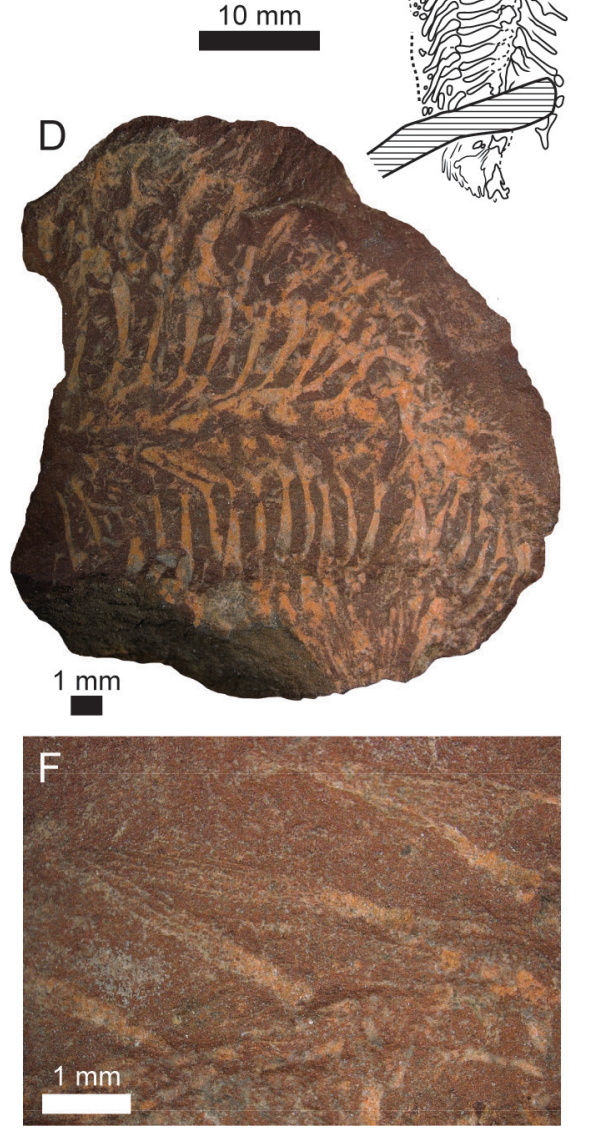

Fig. 3. Savignaster septentrionalis Rousseau \& Gale sp. nov. A-B. Holotype PMO 218.000 . A. Complete arm and associated interradial area showing chevron ossicles. B. Drawing of holotype showing main morphological features. C. Paratype PMO 217.976, partial arm preserved up to the tip. D. Paratype PMO 217.977, partial arm specimen with elongated, narrow ambulacrals set at nearly right-angle to the arm axis. E. Paratype PMO 217.978, a near complete arm with associated adambulacral spines. F. Paratype PMO 218.008, close-up view of fan-shaped trellis-like adambulacral spines articulated to the lateral margin of the adambulacral. Abbreviations: abact = abactinal ossicle; adamb = adambulacral; $\mathrm{amb}=$ ambulacral; cho $=$ chevron ossicle . 


\author{
Class Ophiuroidea Gray, 1840 \\ Ophintegrids of O'Hara et al. 2017 \\ Suborder Ophiacanthina Ljungman, 1867 \\ Family Ophiacanthidae Ljungman, 1867
}

Genus Ophiogaleus Thuy, 2013

\title{
Type species
}

Ophiacantha? constricta Hess, 1966, by original designation.

\section{Extended diagnosis}

Ophiacanthid with disc covered in minute, thin, rounded scales bearing short, conical spines. Radial shields oval, elongate, shorter than three times the disc radius. Jaws long, with small, oval, elongate oral papillae, two to three at the jaw apex and at least five along the jaw edge. Numerous spines (generally at least seven) reaching the length of two arm segments and positioned on ear-shaped spine articulations on a strongly elevated distal portion of lateral arm plates; dorsal and ventral lobes of spine articulations merged into continuous lobe; outer surface of lateral arm plates with moderately coarsely meshed stereom; ridge on inner side composed of short, narrow, oblique central part with generally strongly widened, triangular dorsal portion with nearly vertical distal edge and pointed dorsal and ventro-proximal tips; generally several spurs at least on inner distal edge of lateral arm plates; arm spines forming fan dorsally at least in proximal arm segments; row of spine articulations commonly protruding ventrally. Ventral portion of lateral arm plate wide and abutting along the arm midline on at least half the length of an arm segment. One to two rounded triangular tentacle pores.

\section{Ophiogaleus sp.}

Figs $4-5$

\section{Material examined}

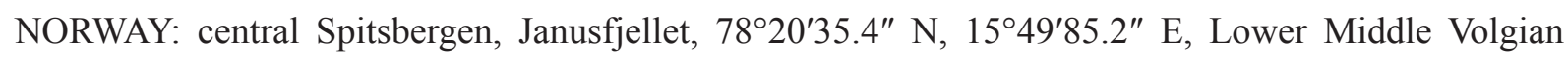
(Middle Tithonian), Slottsmøya Member, Agardhfjellet Formation (PMO 217.899a); central Spitsbergen, Konusdalen, $78^{\circ} 19^{\prime} 97.1^{\prime \prime} \mathrm{N}, 15^{\circ} 52^{\prime} 15.5^{\prime \prime} \mathrm{E}$, from the same layer of sideritic concretions (PMO 218.053a, PMO 218.060). In total, 9 specimens were collected from the Janusfjellet and Konusdalen sites.

\section{Description}

PMO 217.899a (Fig. 4) is an articulated disc with five fragmentary arms and with the splitting plane close to the ventral side of the skeleton. The disc is distorted and the reconstructed diameter is $14.9 \mathrm{~mm}$ (average of narrowest $11.7 \mathrm{~mm}$ and broadest $18.0 \mathrm{~mm}$ ).

The oral plates are long and devoid of lateral wings. The dental plates (Fig. 4B-C) have two or three very small, blunt oral apical papillae. The lateral oral papillae are not unambiguously discernible, but seem to be similar to the apical ones. The adoral shields are long and slender, but their exact outline is not visible. The oral shields (Fig. 4B-C) are small and nearly pentagonal with concave proximal and latero-distal edges.

The interradial areas (Fig. 4B-C) are not indented and covered by moderately dense, small, conical spines, three to four times as long as thick. The interradial disc scales, if present at all, must have been very thin. The radial shields are elongated, oval to slightly pear-shaped, around three times as long as broad and about one fourth of the disc radius. The adradial genital plates are long and slender, longer 
ROUSSEAU J. et al., New articulated asteroids and ophiuroids from the Jurassic of Spitsbergen

than the radial shield, while the abradial genital plates are bar-like and a third of the adradial genital plates in length.

The six basalmost arm segments are incorporated into the disc. The longest preserved arm has a length of $24.5 \mathrm{~mm}$ from the edge of the disc onwards and comprises 20 segments. The arms taper very slowly, suggesting a considerable original arm length. The proximal arm segments are wider than long, while the distalmost arm segment is nearly as wide as long. The tentacle pores are moderately large, developed as between-plate openings on all segments preserved. The lateral arm plates present a strongly bulging distal portion bearing spine articulations, which gives a clearly noded aspect to the arm segments (Fig. 4D). The outer surface of the lateral arm plates seems to be coarsely reticulated, but details are not well preserved. The spine articulations are ear-shaped, large and free-standing on the bulging distal portion of the lateral arm plates. The spines are erect, slender, conical and seemingly smooth. The spine length equals the length of two segments. There are at least five spines proximally. The lateral arm plates abut ventrally from the proximal-most segments onwards. The outline of the ventral arm plates is not discernible on specimen PMO 217.899a.

PMO 218.060 (Fig. 5A-E) is an articulated disc preserving portions of all five arms and visible on two slabs of rock as a part (PMO 218.060a, Fig. 5A) and counterpart (PMO 218.060b, Fig. 5B). The specimen is similar to PMO 217.899a with respect to disc and arm morphology, but supplements the latter in some aspects. The lateral oral papillae are small, elongate, oval, and similar in size and shape to the apical oral papillae. Due to incipient disarticulation, the disposition of the lateral oral papillae is not clearly visible, although it seems as if they formed a single loosely contiguous row along the jaw edge with at least five lateral papillae per half-jaw. The interradial disc scales are better visible than in the previously described specimen. They are thin, minute, and circular to oval in outline (Fig. 5A, C). One median to distal arm segment (Fig. 5E) is preserved in cross section and shows a dorso-ventrally compressed, oval arm section with the ventro-distal portions of the lateral arm plates slightly protruding ventralwards and at least seven arm spines per lateral arm plate forming an almost continuous collar around the arm.

PMO 218.053a (Fig. 5F) is a partly disarticulated arm portion composed of three median segments. The specimen is well in agreement with those previously described in terms of arm morphology, but provides further insights into the ventral side of the arms. The ventral portion of the lateral arm plate is wide and contiguous over half of the arm segment length. The ventral arm plate is roughly diamondshaped, much wider distally than proximally, with convex distal edge, concave latero-proximal edges and pointed proximal tip. The tentacle pores are encompassed by lateral and ventral arm plates and covered by two elongate, rounded triangular tentacle scales.

\section{Remarks}

The long, erect arm spines positioned on the strongly bulging distal portion of the lateral arm plates, giving the arms a conspicuously noded aspect, in combination with the disc spines, the ear-shaped arm spine articulations and the oral plates devoid of lateral wings, unquestionably place the Spitsbergen specimens in the suborder Ophiacanthina (formerly the family Ophiacanthidae as understood prior to the new classification of O'Hara et al. 2017). Within this group, closest affinities are shared with Ophiogaleus, an extinct genus described by Thuy (2013) on the basis of articulated arm fragments and dissociated lateral arm plates. Shared features pertain to the lateral arm plates with the strongly bulging and ventrally protruding distal portion, the wide ventral portion in median to distal arm segments, and the coarsely meshed outer surface stereom, the numerous arm spines forming a nearly continuous fan dorsally, as well as the rounded triangular tentacle scales. No other known extant or extinct ophiacanthinid presents this combination of characters. We thus assign the here-described specimens to Ophiogaleus, albeit in open nomenclature as the lateral arm plates preserve insufficient detail for an unambiguous species-level identification. 

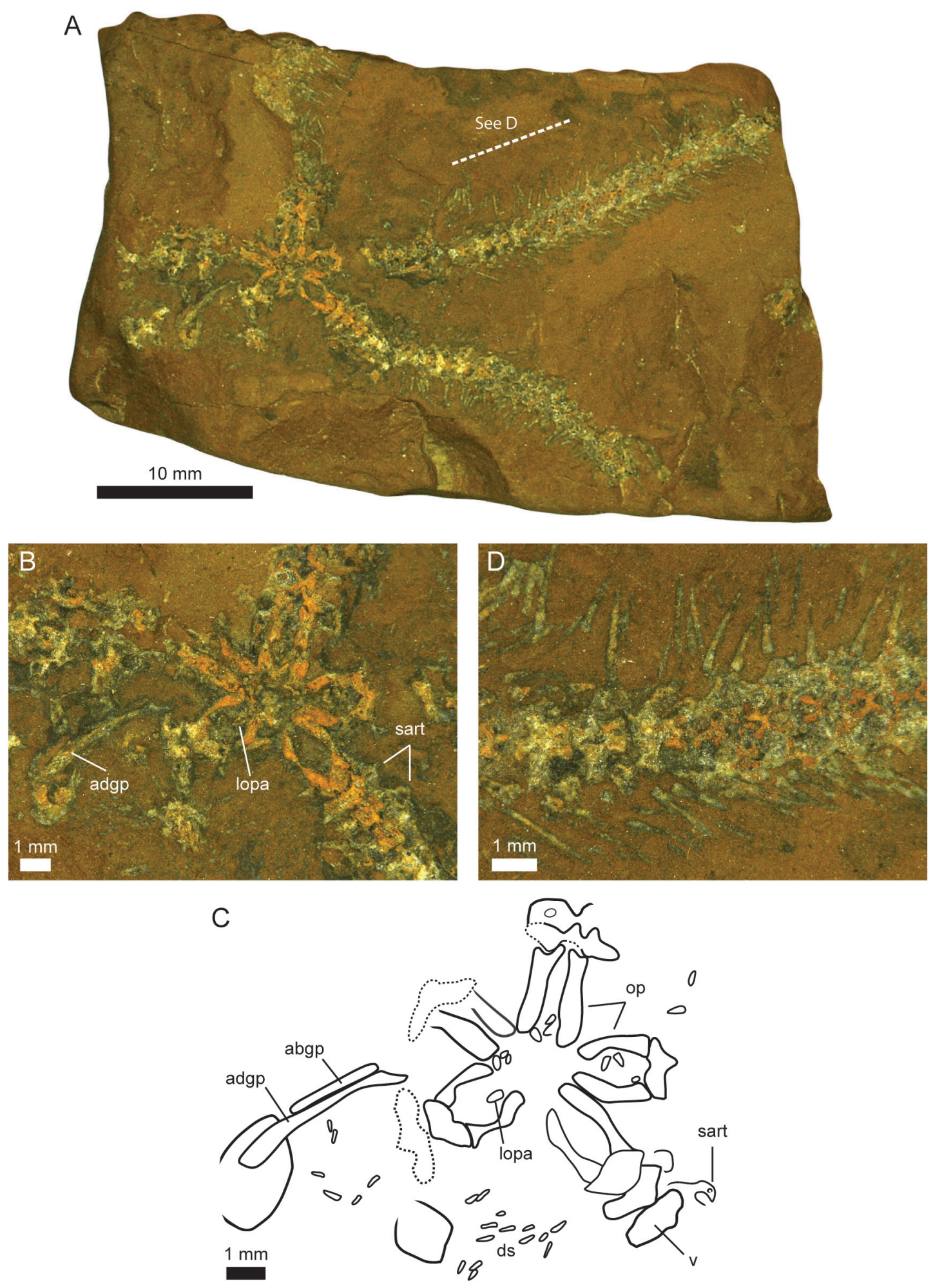

Fig. 4. Ophiogaleus sp. PMO 217.899a. A. Specimen preserving the ventral side of the disc area, two nearly complete arms and proximal area of a third arm. B. Detail view of the disc area. C. Drawing detail of the area shown in B. D. Detail view of a proximal section of arm. Abbreviations: abgp = abradial genital plate; adgp = adradial genital plate; ds = disc spine; lopa = lateral oral papillae; $o p=$ oral plate; sart $=$ spine articulation; $\mathrm{v}=$ vertebra. 

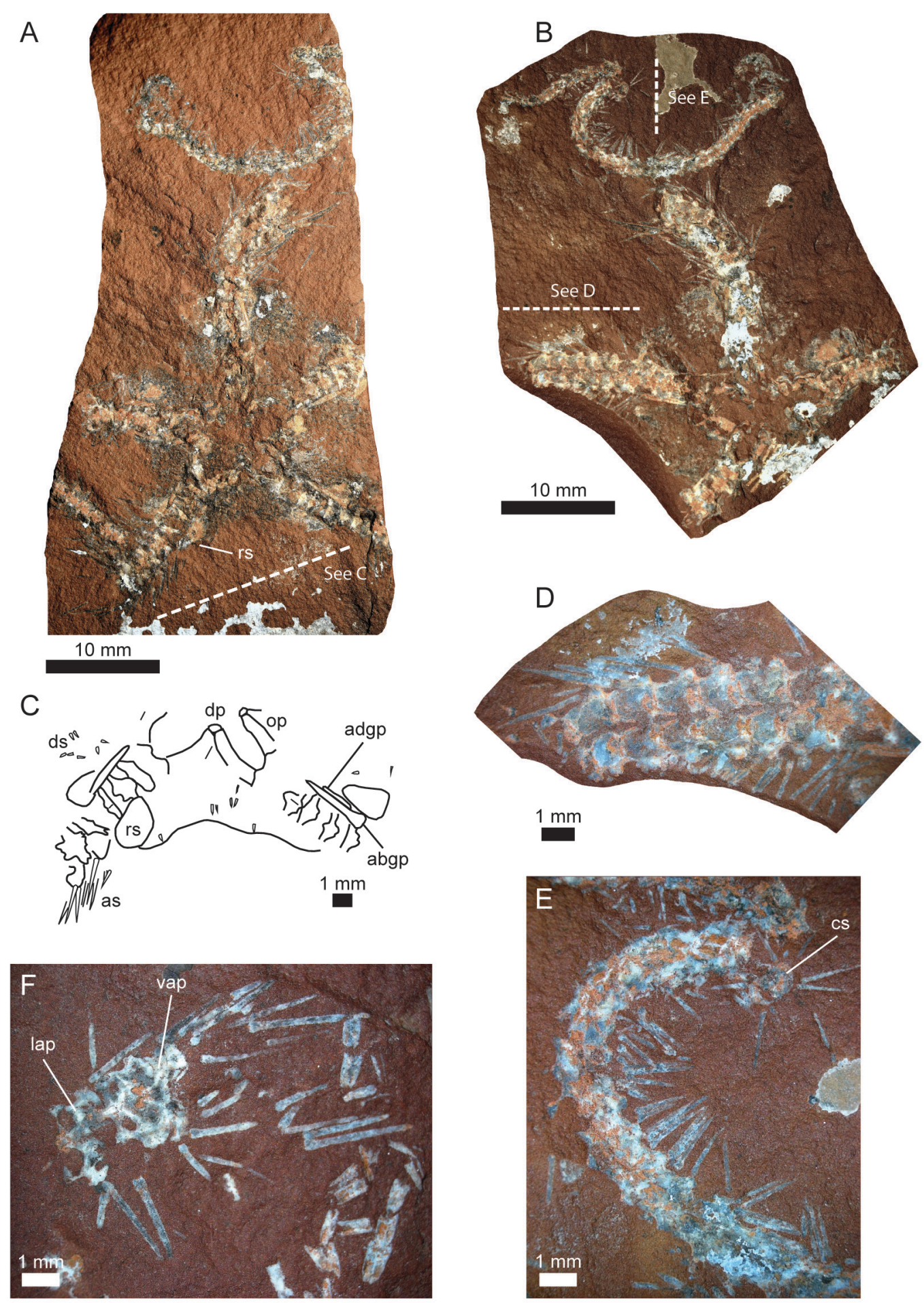

Fig. 5. Ophiogaleus sp. A-E. PMO 218.060, specimen preserving the ventral side of the disc area and the base of all five arms. The specimen has been split through a horizontal plane and is visible as part (A) and counterpart (B). Photographs in A and B by H.A. Nakrem. C. Drawing detail of the oral and interradial area. D. Detail view of proximal arm segments with articulated spines. E. Detail view of distal arm segment. F. PMO 218.053a, partly disarticulated arm portion composed of three median segments showing details of the ventral side of the arms. Abbreviations: abgp = abradial genital plate; $\operatorname{adg} p=$ adradial genital plate; $a$ s $=$ arm spine $; c s=\operatorname{arm}$ in cross section; $\mathrm{dp}=$ dental plate; $d s=$ disc spine; lap = lateral arm plate; op = oral plate; $r s=$ radial shield; vap = ventral arm plate. 
The present material falls within the known stratigraphic range of Ophiogaleus (Sinemurian to Maastrichtian) (Thuy 2013), but extends the palaeogeographical range of the genus to polar latitudes. It furthermore stands out in representing the first finds of complete, articulated skeletons of Ophiogaleus providing insights into the previously unknown disc morphology and allowing to significantly extend the diagnosis of the genus. Since exhaustively known fossil ophiuroids play a pivotal role in phylogenetic estimates (Thuy \& Stöhr 2016), the Spitsbergen Ophiogaleus material significantly adds to the dataset available for the systematic reconstruction of ophiuroid evolutionary history (O’Hara et al. 2017).

In the original description of Ophiogaleus, Thuy (2013) postulated close phylogenetic ties with the extant genus Ophiacantha Müller \& Troschel, 1842 on the basis of similarities in lateral arm plate morphology. Indeed, the new insights on disc morphology of Ophiogaleus fall within the spectrum of the extant members of the family Ophiacanthidae as recently circumscribed by O'Hara et al. (2017) with its type genus Ophiacantha. However, due to the absence of family-level diagnoses for the new classification by O'Hara et al. (2017), it is currently not possible to provide compelling evidence in favour of such an assignment. Ophiogaleus might, in fact, belong to a yet unknown extinct family sister to the Ophiacanthidae. With the present knowledge at hand, however, the most conservative approach is an assignment to the Ophiacanthidae.

Ophiogaleus sp. was probably a suspension feeder and used its long, robust, erect arm spines to trap food particles, as do some modern suspension-feeding ophiacanthids (O'Hara \& Stöhr 2006; Hess \& Meyer 2008). Its occurrence at shelf depths is not unusual as the late Jurassic was a time of exceptionally abundant and diverse ophiacanthid records in shallow waters (Thuy 2013). Modern ophiacanthids are most common and diverse at bathyal depths, although shallower occurrences are not uncommon, especially at high latitudes.

Euryophiurids of O'Hara et al. 2017

Order Ophiurida Müller \& Troschel, 1840

Suborder Ophiurina Müller \& Troschel, 1840

Family Ophiopyrgidae Perrier, 1893

Ophioculina Rousseau \& Thuy gen. nov. urn:Isid:zoobank.org:act:E82E3C6B-7193-4082-9FDD-6549411E1EFB

\section{Type species}

Ophioculina hoybergia Rousseau \& Thuy gen. et sp. nov., by original designation.

\section{Diagnosis}

Dorsal disc with numerous, small, thin scales. Well-developed arm comb. Tentacle pores developed as between-plate openings pointing ventro-distalwards until median arm then reduced to within-plate perforations.

\section{Etymology}

From the Latin 'culina', kitchen, since most of the specimens where discovered accidentally while clearing a surface area for the kitchen tent of the 2010 field camp. 
ROUSSEAU J. et al., New articulated asteroids and ophiuroids from the Jurassic of Spitsbergen

Ophioculina hoybergia Rousseau \& Thuy gen. et sp. nov. urn:1sid:zoobank.org:act:9832EAD6-F33E-4E37-9F38-0ADB944CBE4F

Figs 6-7

\section{Diagnosis}

As for genus.

\section{Etymology}

In honor of Magne Høyberget, who greatly contributed to the collection of the echinoderm fossils from Spitsbergen and to Norwegian palaeontology.

\section{Material examined}

\section{Holotype}

NORWAY: central Spitsbergen, Konusdalen, 78¹9'97.1" N, 1552'15.5” E (PMO 217.930).

\section{Paratypes}

NORWAY: same data as for holotpye (PMO 218.010b, PMO 218.048); central Spitsbergen, Janusfjellet, $78^{\circ} 20^{\prime} 35.4^{\prime \prime} \mathrm{N}, 15^{\circ} 49^{\prime} 85.2^{\prime \prime} \mathrm{E}$ (PMO 218.001c). More than 80 specimens each consisting of an articulated disc and at least the basal portion of one or more arms have been collected from the Janusfjellet and Konusdalen sites. A large amount of intermingled isolated arm fragments were also present in the samples.

\section{Type stratum}

Lower Middle Volgian (Middle Tithonian), Slottsmøya Member, Agardhfjellet Formation.

\section{Description}

PMO 217.930 (Fig. 6A-D) is a fragment of an articulated disc preserving the basal portions of three arms. The specimen is split close to the ventral side. The disc is round and has a diameter of $25.3 \mathrm{~mm}$. The oral plates are long, stout and separated into two seemingly unfused halves (Fig. 6D). The adoral shields are insufficiently preserved on the holotype to provide an accurate description. The oral shields have a narrow rectangular distal portion and a much wider proximal portion which is, however, insufficiently preserved for an unambiguous description. Each dental plate bears a cluster of three small, conical apical oral papillae bordered by a seemingly continuous row of similarly small, uniform, pointed lateral oral papillae, most probably six or seven in number. The second oral tentacle pores are superficial and covered by at least three papillae that are slightly larger than the lateral oral papillae and seemingly form a separate row.

The interradial areas (Fig. 6D) are not indented and covered by small, thin, rounded scales rather uniform in size. The interradial disc plates are devoid of granules or other spines.

The genital slits are bordered on both sides by small (abradial side of slit) to very small (adradial side), block-like papillae which seem to have originally formed a continuous row. The adradial and abradial genital plates are nearly equal in length. The adradial ones are uniformly slender and bar-like while the abradial plates are flat, with a broadened distal portion reminiscent of a hockey stick, and with a longitudinal ridge. The distal edge of the abradial genital plate bears a continuous row of small, blocklike, blunt papillae similar in shape and size to those lining the abradial edge of the genital slit, and forming a well-developed arm comb (Fig. 6C). 
The six most proximal arm segments are incorporated within the disc. The tentacle pores are enclosed by lateral and ventral arm plates and developed at least until the eighth segment counted from the first segment that is not incorporated into the disc. The pores rapidly decrease in size distalwards. There are at least three very small tentacle scales on the lateral arm plate part of the proximal tentacle pores. The lateral arm plates abut ventrally from the most proximal segments onwards. They are slightly bulging, but not constricted. The ornamentation of the outer surface is not discernible. There are two to three slender spines, the longest of which nearly equals the length of one segment, on each lateral arm plate (Fig. 6C). The outline of the ventral arm plates is not discernible from the holotype.

Paratype 218.001c (Fig. 7A-B) is an articulated disc preserving most of the five arms and exposing the ventral side. Disc diameter is $9.7 \mathrm{~mm}$. Five arm segments are incorporated into the disc. The longest arm is $32 \mathrm{~mm}$ long and slowly tapering. It comprises 24 segments counted from the edge of the disc. Proximal segments are wider than long, distalmost segments are clearly elongated. The tentacle openings are developed as pores enclosed by the ventral and lateral arm plates until the eighth segment counted from the disc edge, and developed as perforations within the lateral arm plates in all the following segments, emerging below the ventralmost spine articulation. The lateral arm plates are ventrally abutting in all arm segments. The ventral arm plates are asymmetrically lozenge-shaped and nearly two times wider
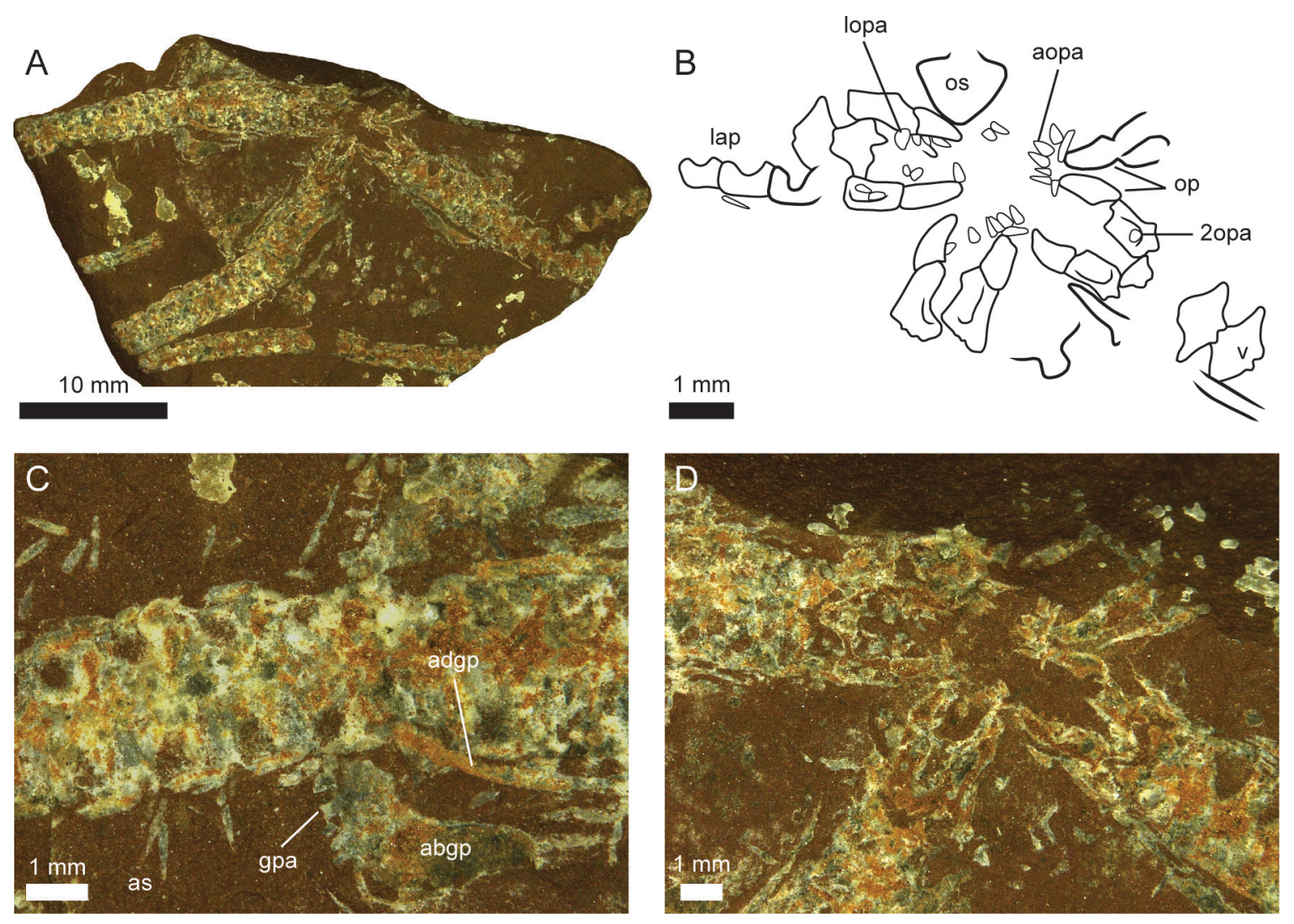

Fig. 6. Ophioculina hoybergia Rousseau \& Thuy gen. et sp. nov., holotype PMO 217.930. A. Specimen preserving the ventral side of about half of the disc area and the proximal section of three arms. B. Drawing detail of the oral region, from D. C. Detail view of the base of an arm showing the arm comb. D. Detail view of the oral region. Abbreviations: abgp = abradial genital plate; adgp = adradial genital plate; aopa $=$ apical oral papilla; as $=$ arm spine; gpa $=$ genital papilla; lap = lateral arm plate; lopa $=$ lateral oral papilla; op $=$ oral plate; os $=$ oral shield $; \mathrm{v}=$ vertebra; 2 opa $=$ papilla of the second oral tentacle pore. 
ROUSSEAU J. et al., New articulated asteroids and ophiuroids from the Jurassic of Spitsbergen

than long in all segments. Their proximal edge is pointed with an obtuse angle, while their distal edge is slightly convex. The spine articulations are small, sunken into a shallow, dorso-ventral incision of the lateral arm plate outer surface at some distance from the distal edge of the plate. The microstructure of the spine articulations is not discernible. There are at least two spines on each lateral arm plate, but the actual number is not discernible. The outer surface of lateral arm plate is finely meshed stereom devoid of constrictions or conspicuous ornamentation. The presence of spurs on the outer proximal edge of the lateral arm plates cannot be assessed.

Paratype PMO 218.048 (Fig. 7C) is an articulated disc with the basal portion of two arms preserved. It is split close to the ventral side and its morphology is in agreement with that of the holotype. The oral plates, the second oral tentacle pores and the rows of papillae bordering the genital slit are better preserved and complement or unambiguously corroborate the observations made on the holotype. The oral shield is arrow-shaped with a right to acute proximal angle and a much narrower rectangular distal portion. The adoral shields are narrow, L-shaped and with pointed, abutting proximal tips.

Paratype PMO 218.010b (Fig. 7D-E) is an articulated, complete dorsal disc preserving basal portion of five arms. The disc diameter is $21.8 \mathrm{~mm}$. The specimen is split closer to the dorsal side than the holotype. The dorsal disc is covered by small, rounded, thin and uniform scales. The radial shields are thicker than the dorsal disc scales, shaped as rounded, isosceles triangles about one and a half times longer than wide. They are about a quarter of the disc radius in length. The radial shields are distally separated from the arm base by the distal portion of the abradial genital plate that bears a continuous row of small, round to square-like papillae. The dorsal arm plates are not visible. The section of the lateral arm plates suggests a rather thin plate architecture.

\section{Remarks}

The combination of an arm comb and superficial second oral tentacle pores unambiguously places the Spitsbergen specimens in the suborder Ophiurina as recently circumscribed by O'Hara et al. (2017). The suborder currently includes the Astrophiuridae with the highly modified, asteroid-like Astrophiura Sladen, 1879 and its relatives, the Ophiuridae with the type taxon Ophiura ophiura Linnaeus, 1758 and the genera Ophiocrossota Clark, 1928, Ophiocten Lütken, 1855, Ophioctenella Tyler et al., 1995 and Ophionotus Bell, 1902, and the Ophiopyrgidae comprising most of the remaining genera of the former subfamily Ophiurinae (Smith et al. 1995).

Assignment to the Astrophiuridae can be ruled out as the specimens from Spitsbergen lack the highly diagnostic characters of the group. With the other two families of the suborder, however, matters are more complicated. While the specimens from Spitsbergen resemble recent Ophiura ophiura with respect to disc morphology and arm skeleton, in particular the orientation of the tentacle notch on the inner side of the lateral arm plate, the development of the tentacle pores in median to distal arm segments rule out most members of the Ophiuridae. Ophiura ooplax (H.L. Clark, 1911) is an exception within the Ophiuridae in having tentacle pores developed as within-plate perforations on almost all arm segments. With respect to lateral arm plate morphology, in particular the outer surface ornamentation and the development of the spine articulations, however, it differs significantly from the specimens described herein.

The Ophiopyrgidae include the genera Aspidophiura Matsumoto, 1915, Euvondrea Fell, 1961 and Ophioplinthus Lyman, 1878 which combine within-plate tentacle pores and an overall lateral arm plate morphology comparable to that seen in the Spitsbergen specimens. Assignment to any of these genera is nevertheless precluded since they have rudimentary arm combs and within-plate tentacle pores on almost all arm segments outside the disc rather than on median and distal ones only. We therefore propose the new genus Ophioculina gen. nov. to accommodate the here-described material. 

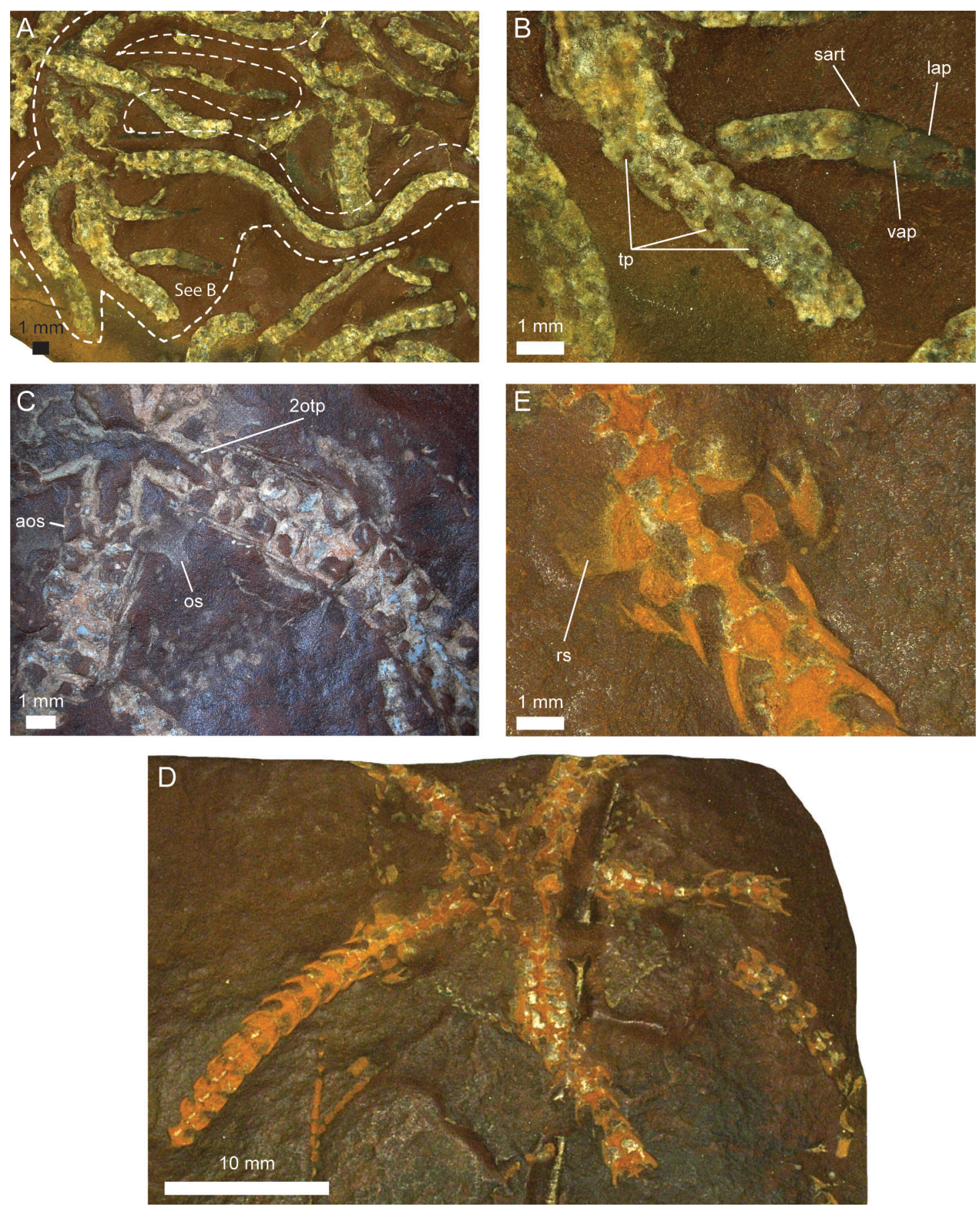

Fig. 7. Ophioculina hoybergia Rousseau \& Thuy gen. et sp. nov., paratypes. A-B. Paratype PMO 218.001c. A. Nearly complete specimen (outlined) preserving five arms and the ventral side of the disc, on a concretion slab with an accumulation of specimens. B. Detail view of arm section. C. Paratype PMO 218.048. Articulated ventral disc preserving good details of the oral plates, the second oral tentacle pores and the rows of papillae bordering the genital slit. D-E. Paratype PMO 218.010b. D. Articulated specimen preserving the basal portion of five arms and showing details of the dorsal disc. E. Detail view of arm section. Abbreviations: aos $=$ adoral shield; lap = lateral arm plate; os $=$ oral shield; $r$ s = radial shield; sart $=$ spine articulation; $\mathrm{tp}=$ tentacle pore; vap $=$ ventral arm plate; 2 otp $=$ second oral tentacle pore. 
ROUSSEAU J. et al., New articulated asteroids and ophiuroids from the Jurassic of Spitsbergen

A definite family-level assignment is hampered by the absence of diagnoses for the clades of O'Hara et al. (2017). Since Ophioculina gen. nov. shares greatest similarities with members of the Ophiopyrgidae, we tentatively place it in this family.

Ophioculina hoybergia gen. et sp. nov. likely used its relatively long, flexible arms for locomotion, while the short arm spines might have been used to gather carrion, detritus or prey (see Hess \& Meyer 2008). At Janusfjellet, specimens of Ophioculina hoybergia gen. et sp. nov. are found stacked up in multiple monospecific layers which may have originated from gregarious behavior of living individuals as commonly seen in modern members of the Ophiurina (e.g., Fujita \& Ohta 1990).

\section{Discussion}

Recent phylogenetic works for both Asteroidea (Gale 2011a; Mah \& Blake 2012; Villier et al. 2017) and Ophiuroidea (O'Hara et al. 2014, 2017; Hunter et al. 2016; Thuy \& Stöhr 2016) have greatly improved our understanding of the family tree of these two echinoderm classes. Complete body fossils of asteroids and ophiuroids being very rare, disarticulated fossils have been increasingly used with success to calibrate phylogenies based on recent taxa (Gale 2011a; O'Hara et al. 2014). Nevertheless, the relationships between extant and fossil taxa remain hard to establish as determination of the phylogenetic meaningfulness of morphological characters is difficult. Specimen completeness is an important factor when attempting to establish robust phylogeny using morphological characters. The exceptional preservation of the Spitsbergen specimens provides near-exhaustive insights into their morphology and could thus help resolve some of these issues and better integrate fossil morphology with recent molecular data.

The asterozoan fauna described here is also part of a bigger snapshot of life from a specific time and place. The Slottsmøya Lagerstätte (Hurum et al. 2012) preserves a whole marine ecosystem with abundant fossil vertebrates, macroinvertebrates and microfossils. Detailed descriptions of each of these components is underway and will result in a wealth of data for potential palaeoecology studies. Understanding fossil species within their ecological context is not always possible and Lagerstätten provide a unique opportunity for such in-depth studies. In the long run, the echinoderms presented here will contribute to a better understanding of a complex palaeoenvironment.

Even though the Late Jurassic-Early Cretaceous was a period of major environmental and biotic upheaval, it is still a poorly understood interval of the history of life (Tennant et al. 2017). Most of the currently known diversity of Tithonian marine invertebrates comes from either continental Europe or North America (Tennant et al. 2017). As demonstrated in the introduction, the fossil record of echinoderms from high latitudes is very scarce. The Spitsbergen asteroids and ophiuroids presented here are the northernmost fossil echinoderms to have ever been described and thus significantly add to the extremely limited Mesozoic Boreal asteroids and ophiuroids fossil record. This study consequently represents a significant addition to our knowledge of fossils from this time interval. It also expands our knowledge of Mesozoic asterozoan distribution beyond the traditionally well-studied areas of the Northwest Tethys and thus helps overcome a palaeogeographical sampling bias. Although of low diversity, the asterozoan assemblage described here includes mostly new taxa. Comparisons with coeval assemblages from other palaeogeographic areas are needed to help identify diversity patterns for Tithonian echinoderms. This is of importance since the diversity dynamics of echinoderms through time are not as well understood as for other marine invertebrate groups (Alroy 2010). Moreover, the fossil record for the northern hemisphere is generally better than for the southern hemisphere during the Late Jurassic time interval (Tennant et al. 2017). Future collection efforts in the southern hemisphere and in other poorly known areas of the northern hemisphere are needed to reduce the sampling bias effect on analyses of biodiversity and macro-evolutionary patterns for the Late Jurassic. 


\section{Acknowledgments}

Fieldwork in Svalbard (2008-2011) was financed by the Norwegian Research Council, Norwegian Petroleum Directorate, Spitsbergen Travel, ExxonMobil, Fugro, Statoil, OMV, Powercontrols and Hydro, and by grants nos. EC0425-09 and EC0435-09 from the National Geographic Society. JR also received grants from FQRNT and NSERC PGS-M in 2010-2011. We would like to thank Jørn Hurum, Hans Arne Nakrem, Patrick Druckenmiller, the Spitsbergen Jurassic Research Group and all the volunteers and students who participated in field work seasons on Svalbard, especially Lena Kristensen who discovered the Knorringfjellet site and Magne Høyberget who collected many of the specimens. Sabine Stöhr provided access to the collection of the NRM Stockholm and interesting comments to an early version of this manuscript. Mike Reich provided logistical support at the University of Göttingen.

\section{References}

Allison P.A. 1990. Variation in rates of decay and disarticulation of Echinodermata: implications for the application of actualistic data. Palaios 5: 432-440. https://doi.org/10.2307/3514836

Alroy J. 2010. The shifting balance of diversity among major marine animal groups. Science 329: 11911194. https://doi.org/10.1126/science. 1189910

Ausich W.I. 2001. Echinoderm taphonomy. In: Jangoux M. \& Lawrence J.M. (eds) Echinoderm studies. Vol. 6: 171-227. A.A. Balkema, Rotterdam.

Birkenmajer K., Pugaczewska H. \& Wierzbowski A. 1982. The Janusfjellet Formation (Jurassic-Lower Cretaceous) at Myklegardfjellet, East Spitsbergen. Palaeontologia Polonica 43: 107-140.

Blake D.B. 1987. A classification and phylogeny of post-Paleozoic sea stars (Asteroidea: Echinodermata). Journal of Natural History 21: 481-528. https://doi.org/10.1080/00222938700771141

Blake D.B. 1990. Hettangian Asteriidae (Echinodermata: Asteroidea) from southern Germany: taxonomy, phylogeny and life habits. Paläontologische Zeitschrift 64: 103-123.

https://doi.org/10.1007/BF02985925

Breton G., Bourseau J.-P., Bernier P., Barale G., Buffetaut E., Gaillard C., Gall J.-C. \& Wenz S. 1994. Les astérides (Asteroidea, Echinodermata) des calcaires lithographiques kimméridgiens de Cerin (Ain, France). Geobios 16: 49-60. https://doi.org/10.1016/S0016-6995(94)80020-0

Collignon M. \& Hammer Ø. 2012. Petrography and sedimentology of the Slottsmøya Member at Janusfjellet, central Spitsbergen. Norwegian Journal of Geology 92: 89-101.

Corgan J.X. 1962. A Lower Cretaceous brittle-star from the northern Yukon Territory, Canada. Journal of Paleontology 36: 1108-1111.

Dallmann W.K., Major H., Haremo P., Andresen A., Kjærnet T. \& Nøttvedt A. 2001. Geological map of Svalbard 1:100000, sheet C9G Adventdalen. With explanatory text. Norsk Polarinstitutt Temakart 31/32: 4-55.

Dalseg T.S., Nakrem H.A. \& Smelror M. 2016. Dinoflagellate cyst biostratigraphy, palynofacies, depositional environment and sequence stratigraphy of the Agardhfjellet Formation (Upper JurassicLower Cretaceous) in central Spitsbergen (Arctic Norway). Norwegian Journal of Geology 96 (2): 1-14. https://doi.org/10.17850/njg96-2-04

Delsett L.L., Novis L.K., Roberts A.J., Koevoets M.J., Hammer Ø., Druckenmiller P.S. \& Hurum J.H. 2016. The Slottsmøya marine reptile Lagerstätte: depositional environments, taphonomy and diagenesis. In: Kear B.P., Lindgren J., Hurum J.H., Milàn J. \& Vajda V. (eds) Mesozoic Biotas of Scandinavia and its Arctic Territories: 165-188. Special Publications 434, Geological Society, London. https://doi.org/10.1144/SP434.2 
ROUSSEAU J. et al., New articulated asteroids and ophiuroids from the Jurassic of Spitsbergen

Ditchfield P.W. 1997. High northern palaeolatitude Jurassic-Cretaceous palaeotemperature variation: new data from Kong Karls Land, Svalbard. Palaeogeography, Palaeoclimatology, Palaeoecology 130: 163-175. https://doi.org/10.1016/S0031-0182(96)00054-5

Donovan S.K. 1991. The taphonomy of echinoderms: Calcareous multielement skeletons in the marine environment. In: Donovan S.K. (ed) The Processes of Fossilization: 241-269. Belhaven Press, London.

Dypvik H., Nagy J., Eikeland T.A., Backer-Owe K., Andresen A., Haremo P., Bjærke T., Johansen H. \& Elverhøi A. 1991. The Janusfjellet subgroup (Bathonian to Hauterivian) on central Spitsbergen: a revised lithostratigraphy. Polar Research 9: 21-43. https://doi.org/10.3402/polar.v9i1.6777

Ershova E.S. 1983. Explanatory Notes for the Biostratigraphical Scheme of the Jurassic and Lower Cretaceous Deposits of Spitzbergen Archipelago. PGO Sevmorgeologia, Leningrad. [In Russian.]

Fisher W.K.1928. Asteroidea of the North Pacific and adjacent waters, Part 2. Forcipulata. Bulletin of the United States National Museum 76: 1-404.

Fujita T. \& Ohta S. 1990. Size structure of dense populations of the brittle star Ophiura sarsii (Ophiuroidea: Echinodermata) in the bathyal zone around Japan. Marine Ecology Progress Series 64: 113-122.

Fürsich F.T. 1984a. Palaeoecology of Boreal invertebrate faunas from the Upper Jurassic of central East Greenland. Palaeogeography, Palaeoclimatology, Palaeoecology 48: 309-364. https://doi.org/10.1016/0031-0182(84)90050-6

Fürsich F.T. 1984b. Benthic macroinvertebrate associations from the Boreal Upper Jurassic of Milne Land, central East Greenland. Grønlands Geologiske Undersøgelse Bulletin 149: 1-72.

Gale A.S. 2011a. Phylogeny of the Neoasteroidea (post-Palaeozoic Asteroidea, Echinodermata). Special Papers in Palaeontology 85: 1-112.

Gale A.S. 2011b. Asteroidea (Echinodermata) from the Oxfordian (Late Jurassic) of Savigna, Département du Jura, France. Swiss Journal of Palaeontology 130: 69-89.

https://doi.org/10.1007/s13358-010-0008-x

Gale A.S. \& Villier L. 2013. Mass mortality of an asteriid starfish (Forcipulatida, Asteroidea, Echinodermata) from the late Maastrichtian (Late Cretaceous) of Morocco. Palaeontology 56: 577-588. https://doi.org/10.1111/pala.12002

Gerasimov P.A., Mitta V.V. \& Kochanova M.D. 1995. Fossils of the Volgian Stage of central Russia. VNIIGRI, Moscow. [In Russian.]

Gerasimov P.A., Mitta V.V., Kochanova M.D. \& Tesakova E.M. 1996. Fossils of the Callovian Stage of central Russia. VNIIGRI, Moscow. [In Russian.]

Goldring R. \& Stephenson D.G. 1972. The depositional environment of three starfish beds. Neues Jahrbuch für Geologie und Paläontologie, Monatschefte 10: 611-624.

Hammer Ø., Nakrem H.A., Little C.T.S., Hryniewicz K., Sandy M.R., Hurum J.H., Druckenmiller P.S., Knutsen E.M. \& Høyberget M. 2011. Hydrocarbon seeps from close to the Jurassic-Cretaceous boundary, Svalbard. Palaeogeography, Palaeoclimatology, Palaeoecology 306: 15-26.

https://doi.org/10.1016/j.palaeo.2011.03.019

Hammer Ø., Nakrem H.A. \& Collignon M. 2012. Organic carbon isotope chemostratigraphy and cyclostratigraphy in the Volgian of Svalbard. Norwegian Journal of Geology 92: 103-112.

Hess H. 1972. Eine Echinodermen-Fauna aus dem mittleren Dogger des Aargauer Juras. Schweizerische Paläontologische Abhandlungen 92: 1-87.

Hess H. \& Meyer C. 2008. A new ophiuroid (Geocoma schoentalensis sp. nov.) from the Middle Jurassic of northwestern Switzerland and remarks on the family Aplocomidae Hess, 1965. Swiss Journal of Geosciences 101: 29-40. https://doi.org/10.1007/s00015-008-1253-5 
Hjálmarsdóttir H.R., Nakrem H.A. \& Nagy J. 2012. Foraminifera from Late Jurassic-Early Cretaceous hydrocarbon seep carbonates, central Spitsbergen, Svalbard - preliminary results. Norwegian Journal of Geology 92: 157-165.

Houša V., Pruner P., Zakharov V.A., Košt'ák M., Chadima M., Rogov M.A., Šlechta S. \& Mazuch M. 2007. Boreal-Tethyan correlation of the Jurassic-Cretaceous boundary interval by magneto- and biostratigraphy. Stratigraphy and Geological Correlation 15: 297-309.

https://doi.org/10.1134/S0869593807030057

Hryniewicz K., Hammer Ø., Nakrem H.A. \& Little C.T.S. 2012. Microfacies of the Volgian-Ryazanian (Jurassic-Cretaceous) hydrocarbon seep carbonates from Sassenfjorden, central Spitsbergen, Svalbard. Norwegian Journal of Geology 92: 113-131.

Hryniewicz K., Nakrem H.A., Hammer Ø., Little C.T.S., Kaim A., Sandy M.R. \& Hurum J.H. 2015. The palaeoecology of the latest Jurassic - earliest Cretaceous hydrocarbon seep carbonates from Spitsbergen, Svalbard. Lethaia 48: 353-374. https://doi.org/10.1111/let.12112

Hunter R.L., Brown L.M., Alexander Hill C., Kroeger Z.A. \& Rose S.E. 2016. Additional insights into phylogenetic relationships of the Class Ophiuroidea (Echinodermata) from rRNA gene sequences. Journal of Zoological Systematics and Evolutionary Research 54 (4): 269-275.

https://doi.org/10.1111/jzs.12135

Hurum J.H., Nakrem H.A., Hammer Ø., Knutsen E.M., Druckenmiller P.S., Hryniewicz K. \& Novis L.K. 2012. An Arctic Lagerstätte - the Slottsmøya Member of the Agardhfjellet Formation (Upper JurassicLower Cretaceous) of Spitsbergen. Norwegian Journal of Geology 92: 55-64.

Jeletzky J.A. 1973. Biochronology of the marine boreal latest Jurassic, Berriasian and Valanginian in Canada. In: Casey R. \& Rawson P.F. (eds) The Boreal Lower Cretaceous. Geological Journal Special Issue 5: 41-80.

Koevoets M.J., Abay T.B., Hammer Ø. \& Olaussen S. 2016. High-resolution organic carbon-isotope stratigraphy of the Middle Jurassic-Lower Cretaceous Agardhfjellet Formation of central Spitsbergen, Svalbard. Palaeogeography, Palaeoclimatology, Palaeoecology 449: 266-274.

https://doi.org/10.1016/j.palaeo.2016.02.029

Lewis R.D. 1986. Relative rates of skeletal disarticulation in modern ophiuroids and Paleozoic crinoids. Geological Society of America Abstracts with Programs 18: 672.

Lewis R.D. 1987. Post-mortem decomposition of ophiuroids from the Mississippi Sound. Geological Society of America Abstracts with Programs 19: 94-95.

Mah C.L. 2016. World Asteroidea Database. Availble from http://www.marinespecies.org/asteroidea [accessed on 26 Oct. 2016].

Mah C.L. \& Blake D.B. 2012. Global diversity and phylogeny of the Asteroidea (Echinodermata). PLoS ONE 7 (4): e35644. https://doi.org/10.1371/journal.pone.0035644

Martynov A.V. 2010. Reassessment of the classification of the Ophiuroidea (Echinodermata), based on morphological characters. I. General character evaluation and delineation of the families Ophiomyxidae and Ophiacanthidae. Zootaxa 2697: 1-154.

Mørk A., Dallmann W.K., Dypvik H., Johannessen E.P., Larssen G.B., Nagy J., Nøttvedt A., Olaussen S., Pčelina T.M. \& Worsley D. 1999. Mesozoic lithostratigraphy. In: Dallmann W.K. (ed.) Lithostratigraphic Lexicon of Svalbard: 127-214. Norsk Polarinstittutt, Tromsø.

Nagy J. 1963. Echinoderms from the Lower Cretaceous of Vestspitsbergen. Norsk polarinstitutt Arbok 1962: 192-193. 
ROUSSEAU J. et al., New articulated asteroids and ophiuroids from the Jurassic of Spitsbergen

Nagy J. \& Basov V.A. 1998. Revised foraminiferal taxa and biostratigraphy of Bathonian to Ryazanian deposits in Spitsbergen. Micropaleontology 44: 217-255. https://doi.org/10.2307/1486047

Nagy J., Reolid M. \& Rodriguez-Tovar F.J. 2009. Foraminiferal morphogroups in dysoxic shelf deposits from the Jurassic of Spitsbergen. Polar Research 28: 214-221.

https://doi.org/10.1111/j.1751-8369.2009.00112.x

Nance J.M. \& Braithwaite L.F. 1972. The function of mucus secretions in the cushion star Pteraster tesselatus Ives. Journal of Experimental Marine Biology and Ecology 40: 259-266.

O’Hara T.D. \& Stöhr S. 2006. Deep water Ophiuroidea (Echinodermata) of New Caledonia: Ophiacanthidae and Hemieuryalidae. In: Richer de Forges B. \& Justine J.-L. (eds) Tropical DeepSea Benthos 24: 33-141. Mémoires du Muséum national d'Histoire naturelle 193, Muséum national d'Histoire naturelle, Paris.

O'Hara T.D., Hugall A.F., Thuy B. \& Moussalli A. 2014. Phylogenomic resolution of the class Ophiuroidea unlocks a global microfossil record. Current Biology 24 (16): 1874-1879.

https://doi.org/10.1016/j.cub.2014.06.060

O'Hara T.D., Hugall A.F., Thuy B., Stöhr S. \& Martynov A. 2017. Restructuring higher taxonomy using broad-scale phylogenomics: the living Ophiuroidea. Molecular Phylogenetics and Evolution 107: 415-430. https://doi.org/10.1016/j.ympev.2016.12.006

Parker J.R. 1967. The Jurassic and Cretaceous sequence in Spitsbergen. Geological Magazine 104: 487-505.

Rogov M. \& Zakharov V. 2009. Ammonite- and bivalve-based biostratigraphy and Panboreal correlation of the Volgian Stage. Science in China Series D: Earth Sciences 52: 1890-1909.

https://doi.org/10.1007/s11430-009-0182-0

Roman J., Breton G. \& Vadon C. 1993. Ophiurides et asterides (Echinodermata) du Tithonien de Canjuers (Var, France). Annales de Paléontologie 79: 1-18.

Rousseau J. \& Nakrem H.A. 2012. An Upper Jurassic Boreal echinoderm Lagerstätte from Janusfjellet, central Spitsbergen. Norwegian Journal of Geology 92: 133-148.

Schäfer W. 1972. Ecology and Palaeoecology of Marine Environments. Oliver \& Boyd, Edinburg.

Smith A.B., Paterson G.L.J. \& Lafay B. 1995. Ophiuroid phylogeny and higher taxonomy: morphological, molecular and palaeontological perspectives. Zoological Journal of the Linnean Society 114: 213-243. https://doi.org/10.1111/j.1096-3642.1995.tb00117c.x

Spath L.F. 1935. The Upper Jurassic invertebrate faunas of Cape Leslie, Milne Land. I. Oxfordian and Lower Kimmeridgian. Meddelelser om Grønland 99: 1-78.

Spath L.F. 1947. Additional observations on the invertebrates (chiefly ammonites) of the Jurassic and Cretaceous of East Greenland. Meddelelser om Grønland 132: 1-69.

Spencer W.K. \& Wright C.W. 1966. Asterozoans. In: Moore R.C. (ed.) Treatise on invertebrate paleontology. Part U: Echinodermata 3: U4-U107. The Geological Society of America, Washington DC and The University of Kansas Press, Lawrence.

Stöhr S., O'Hara T.D. \& Thuy B. 2012. Global diversity of brittle stars (Echinodermata: Ophiuroidea). PLoS ONE 7 (3): e31940. https://doi.org/10.1371/journal.pone.0031940

Stöhr S., O'Hara T. \& Thuy B. (eds) 2016. World Ophiuroidea database. Available from http://www.marinespecies.org/ophiuroidea [accessed on 26 Oct. 2016].

Tennant J.P., Mannion P.D., Upchurch P., Sutton M.D. \& Price G.D. 2017. Biotic and environmental dynamics through the Late Jurassic-Early Cretaceous transition: evidence for protracted faunal and ecological turnover. Biological Reviews 92: 776-814. https://doi.org/10.1111/brv.12255 
Thuy B. 2013. Temporary expansion to shelf depths rather than an onshore-offshore trend: the shallowwater rise and demise of the modern deep-sea brittle star family Ophiacanthidae (Echinodermata: Ophiuroidea). European Journal of Taxonomy 48: 1-242. https://doi.org/10.5852/ejt.2013.48

Thuy B., Gale A.S. \& Reich M. 2011. A new echinoderm Lagerstätte from the Pliensbachian (Early Jurassic) of the French Ardennes. Swiss Journal of Palaeontology 130: 173-185.

https://doi.org/10.1007/s13358-010-0015-y

Thuy B. \& Stöhr S. 2011. Lateral arm plate morphology in brittle stars (Echinodermata: Ophiuroidea): new perspectives for ophiuroid micropalaeontology and classification. Zootaxa 3013: 1-47.

Thuy B. \& Stöhr S. 2016. A new morphological phylogeny of the Ophiuroidea (Echinodermata) accords with molecular evidence and renders microfossils accessible for cladistics. PLOS ONE 11 (5): e0156140. https://doi.org/10.1371/journal.pone.0156140

Trautschold H. 1866. Zur Fauna des Russischen Jura. Bulletin de la Société impériale des naturalistes de Moscou 39: 1-24.

Trautschold H. 1877. Ergänzung zur Fauna des russischen Jura. Verhandlungen der Russisch-Kaiserlichen Mineralogischen Gesellschaft zu St Petersburg 2: 79-111.

Villier L., Brayard A., Bylund K.G., Jenks J.F., Escarguel G., Olivier N., Stephen D.A., Vennin E. \& Fara E. 2017. Superstesaster promissor gen. et sp. nov., a new starfish (Echinodermata, Asteroidea) from the Early Triassic of Utah, USA, filling a major gap in the phylogeny of asteroids. Journal of Systematic Palaeontology: 1-21. https://doi.org/10.1080/14772019.2017.1308972

Wierzbowski A., Hryniewicz K., Hammer Ø., Nakrem H.A. \& Little C.T.S. 2011. Ammonites from hydrocarbon seep carbonate bodies from the uppermost Jurassic-lowermost Cretaceous of Spitsbergen, Svalbard, and their biostratigraphic importance. Neues Jahrbuch für Geologie und Paläontologie 262: 267-288. https://doi.org/10.1127/0077-7749/2011/0198

Zakharov V.A. \& Rogov M.A. 2008. Let the Volgian stage stay in the Jurassic. Russian Geology and Geophysics 49: 408-412. https://doi.org/10.1016/j.rgg.2007.09.017

Zakharov V.A., Shurygin B.N., Kurushin N.I., Meledina S.V. \& Nikitenko B.L. 2002. A Mesozoic ocean in the Arctic: paleontological evidence. Russian Geology and Geophysics 43: 143-170.

Manuscript received: 28 March 2017

Manuscript accepted: 18 July 2017

Published on: 9 March 2018

Topic editor: Christian de Muizon

Desk editor: Kristiaan Hoedemakers

Printed versions of all papers are also deposited in the libraries of the institutes that are members of the EJT consortium: Muséum national d'Histoire naturelle, Paris, France; Botanic Garden Meise, Belgium; Royal Museum for Central Africa, Tervuren, Belgium; Natural History Museum, London, United Kingdom; Royal Belgian Institute of Natural Sciences, Brussels, Belgium; Natural History Museum of Denmark, Copenhagen, Denmark; Naturalis Biodiversity Center, Leiden, the Netherlands; Museo Nacional de Ciencias Naturales-CSIC, Madrid, Spain; Real Jardín Botánico de Madrid CSIC, Spain. 